(3) M.O.Speidel : Met.Trans., $6 \mathbf{A}(1975), 631$.

(4) H.H.Uhlig and E.Cook Jr. : J.Electrochem. Soc., 116(1969), 173.

(5) R.W.Staehle : The Theory of Stress Corrosion Cracking in Alloys, Ed.by J.C.Scully, NATO, Brussels, (1971), 223.

（6）下平三郎：金属学会会報，13(1974)，779.

(7) S.J.Acello and N.D. Greene : Corrosion, 18 (1962), $286 \mathrm{t}$.

（8）久松敬弘：防蝕技術，21(1972)，503; Localized Corrosion, NACE, $(1974), 427$.

(9) E.Brauns und H. Ternes : Werks. Korr., 19 (1968), 1 .

(10) T.P.Hoar and J.E.Slater : Corr.Sci., 14(1974), 415.

(11) J.D.Harston and J.C.Scully : Corrosion, 25 (1969), 493.

(12) J.D.Harston and J.C.Scully : Corrosion, 26 (1970), 387.

(13) 岡田秀弥, 絒走祐三, 阿部征三郎, 山本州一：金属 学会誌, 37(1973), 197.

(14) 高野道典, R.W. Staehle : 腐食防食協会講演要旨 集, (May, 1975) , p.80.

(15) 辻川茂男，久松敬弘：防蝕技術，25(1976)，67。

(16) 久伀敬弘: 電気化学, $38(1970), 691$; 表偭之反応, 朝倉畫店, (1973), 114 .
(17) 过川茂男，久松敬弘：第 13 回材料強度に関するシ ンポジム予稿集，日本材料学会，(July，1976)， p.112.

(18) R.T.Newberg and H.H.Uhlig: J.Electrochem. Soc., $120(1973), 1629$.

(19) M.Marek and R.F.Hochman : Corrosion, 26 (1970), 5 .

（20）泊里治夫，下郡一利，藤原和雄：腐食防食協会講演 予稿集，(May, 1976)，p.66。

(21) G.Bianchi, F. Mazza and S. Torchio : Corr.Sci., 13(1973), 165 .

(22) 浅輪三男：鉄々鋼, $57(1971), 1340$.

(23) 清田伸一：東京大学修士論文, (1975)

(24) R.E.Reed and H.W. Paxton : First Intern. Congress on Metallic Corrosion, Butterworths, (1962), 301.

(25) J.D.Harston and J.C.Scully : Nature(London), 22(1969), 853 .

(26) 大谷南海男, 伊庭喗邦: 金属学会誌, 33(1969),781.

(27) H.Okada, Y.Hosoi and S.Abe : Corrosion, 26 (1970), 183.

（28）蒲地一義，岾 睦：防蝕技術，24(1975)，641。

(29) 昆 謙造, 大仝南海男: 金属学会誌, $37(1973), 917$; $40(1976), 498$

(30) C.A.Stubbington: Metallurgia, 68(1963), 109.

(31) 久松敂弘, 小玉捘明：軽金属, 19(1969), 358.

(32) 辻川茂男, 久松敬弘：未発表.

\title{
304 鋼の繰返し荷重下における成長性食孔からのき裂発生
}

\section{过川茂男* 久松敬 弘*}

Shigeo Tsujikawa and Yoshihiro Hisamatsu : Corrosion Crack Initiation at Growing Pits on Type 304 Steel under Pulsating Load. Rotary bending fatigue tests of Type 304 steel in $1 \mathrm{~N} \mathrm{H}_{2} \mathrm{SO}_{4}$ containing $0.5 \mathrm{M} \mathrm{NaCl}$ at $25^{\circ} \mathrm{C}$ were conducted in order to study the corrosion crack initiation at the site of a growing pit, in comparison with that in the active potential range. Cracks are found to initiate even at a potential of $0.42 \mathrm{~V}$ which is more noble than the critical pitting potential, $V_{c}=0.41 \mathrm{~V}(\mathrm{SCE})$. In the study of the crack initiation at the pits growing at the potentials less noble than $V_{c}$, the following procedures were adopted. The precracks with appropriate depths, which had been introduced into the specimen at $-0.45 \mathrm{~V}$, developed into hemispherical pits and continued to grow at the passive potentials. Such growing pits are considered to be equivalent to the natural pits growing in the same potential range. The occurrence of crack initiation at the bottom of the growing pits increased markedly in the potential range between 0.1 and $0.3 \mathrm{~V}$ under the condition of potential descent at the sweep rate of $240 \mathrm{~min} / \mathrm{V}$. The fact that the less noble the potential the less deep pits issue cracks could be explained from the requirement that initiating crack must have a growth rate higher than the dissolution rate at the pit bottom. The initiation sites of cracks were observed to be small crystallographic pits with mixed facets of $\{111\}$ and $\{100\}$ formed at the bottom of growing pits during the potential descent. The (100) faceting dissolution at the wall of crystallographic pits would play an important role in crack initiation, as it does in crack initiation in the active potential range.

(Received March 31,1977)

* 東京大学工学部金属材粼学科 (Department of Materials Science, Faculty of Engineering, The University of Tokyo, Tokyo) 


\section{I. 緒論}

オーステナイトステンレス鋼の篮化物矿力府餀割れの加 速試験に仁統的に用いられてきた高濃度沸腾 $\mathrm{MgCl}_{2}$ 溶液 試験が，実祭の割机を必ずしも反映しない(1)ことについ て，再倹討 ${ }^{(2)(3)}$ が行なわれている，高濃度沸腾 $\mathrm{MgCl}_{2}$ 試 駼比いては，試片表面から淔接き裂が貫入し，かつき裂 発生末での期間が愷めて短い(4)(5) という事情のために，食 孔を経打(6)〜(8)してやがてき裂が発生するという，実際に

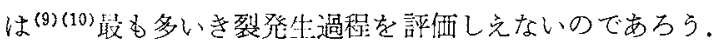

沸腾 $42 \% \mathrm{MgCl}_{2}$ 溶液 ${ }^{(5)(10)}\left(143^{\circ} \mathrm{C}\right), 100^{\circ} \mathrm{C}$ の $33 \sim 35 \%$ $\mathrm{MgCl}_{2}$ 浴液(11)(12)等に括いても，負荷応力の低い場合は大 きな食孔を経由してき裂が発生するという。これらの報告

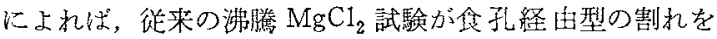
捕ええなかったのは，割れの加速を重視してもっぱら高応 力負荷条件を採用したことによるとも考充ら孙る。

しかし，小若ら ${ }^{(3)}$ は， $80^{\circ} \mathrm{C}$ に液温を下げた $\mathrm{MgCl}_{2}$ 溶液 中試験に打いては，負街応力 $25 \mathrm{~kg} / \mathrm{mm}^{2}$ においても食孔 を経由する割礼が観察でき，かつMoの効果が頀めらるよ らになることを報告した，Moは周知のように耐孔食性を 高める合金元素であり，その効果は，食孔経出型である含

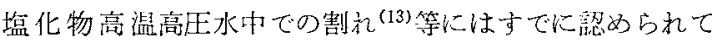
いるが，高濃度沸滕 $\mathrm{MgCl}_{2}$ 試験 ${ }^{(14)}$ では認奶んれなった るのである、先祭に古らき裂発生の条件を柣討するために は，こうした食孔経由型の割れを再現しうる試験が必要で ある。。

Acello ら $5^{(15)} は, 80^{\circ} \mathrm{C}$ の $10 \mathrm{~N} \mathrm{H}_{2} \mathrm{SO}_{4}+0.5 \mathrm{~N} \mathrm{NaCl}$ 溶液 中で $+0.50 \mathrm{~V}(\mathrm{SCE})$ に保ったU曲げ 304 鋼において，激 しい孔俍にもかかからず割れが愁められないことから，孔 食と割れとは互いに独立な別の過程であると考えた。村田 ら ${ }^{(16)}$ 以上れば, $25^{\circ} \mathrm{C}$ の $0.1 \mathrm{~N} \mathrm{H}_{2} \mathrm{SO}_{4}+0.1 \mathrm{M} \mathrm{KCl}$ 溶液中 で 304 鋼細線 $(0.5 \mathrm{~mm} \phi)$ は，170\% または 130\% 降伏応 力下に脆性的破断を起こし，そのときの割礼電位域は無応 力下の孔食電位上り皋な $0.1 \sim 0.3 \mathrm{~V}(\mathrm{SCE})$ であった，食 孔が割れを伴う電位域が孔食のみのそれに近接した卑側比 あるという事笑は， $100^{\circ} \mathrm{C}$ 前後の高濃度塩化物溶液中試験

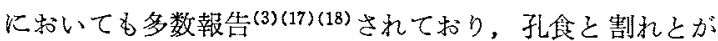
互いに独立な别の過程ではないことを示している。

前報(19) では, 304 鋼の $1 \mathrm{~N} \mathrm{H}_{2} \mathrm{SO}_{4}+0.5 \mathrm{M} \mathrm{NaCl}$ 溶液 $\left(25^{\circ} \mathrm{C}\right)$ 中, 繰返乙荷重下, 活性態域に打㚈るき裂発生につ いて報告した，本報では成長性食孔からのき裂発生をしら ベて，活性態域に打けるとれと比較検討する，繰返し荷重 条件を用いる方法は，かなり大きな速度で溶解している食 孔内壁からもき裂発生を起こしうる点で，実際的に重要な 食孔経由型 SCC き裂の発生条件を解明してゅくためにも 有用であると教觉られる。

\section{II. 実 験 方 法}

とくにのベない場合，実験方法は前報(19)のそれと同じ
である、すなわち，直径 $8.0 \mathrm{~mm}$ の 304 鋼丸棒試片をぐ フ研摩仕上げおよび $1 \mathrm{~N} \mathrm{H}_{2} \mathrm{SO}_{4}$ 中に批りる電気化学的前処 理の後, $1 \mathrm{~N} \mathrm{H}_{2} \mathrm{SO}_{4}+0.5 \mathrm{M} \mathrm{NaCl}$ 水溶液 $\left(25^{\circ} \mathrm{C}\right)$ 中で定電 位保持しつつ繰返乙荷重 (回転洲げ，1300 rpm，応力振幅 $\left.14.6 \mathrm{~kg} / \mathrm{mm}^{2}\right)$ を加之試験した。

不動態域において成長を続ける食孔を作成する方法とし て，孔位電位より貴な電位で食孔を発生さ中試片電位を 下げて不動態域にもちこむというのが自然食孔のとる経

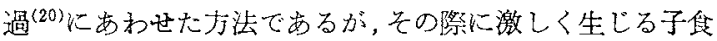
孔が食孔底の锶察を困難にするため，以下の方法を用い た。活性態域に属する電位で導入された適当な深さのき裂 は,試片電位をりかえて不動態域電位に保持主ると,光球

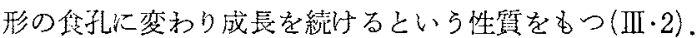
こうして兄られる食孔を，不動態域で成長を綕けている自 然食孔と同等とみなし，こ机からのき裂発生をしらべた。

\section{III，実 験 結 果}

\section{1. 孔食電位以上の電位における食孔からのき裂発生}

本実驗条件 (1300 $\mathrm{rpm}$ ，応力振幅 14.6 和よび $0 \mathrm{~kg} / \mathrm{mm}^{2}$ ) に和计る定常孔食電位 $V_{\mathrm{c}}=0.41 \mathrm{~V}(\mathrm{SCE})$ で方る。平滑試 片を $V_{\mathrm{c}}$ より貴な $0.42 \mathrm{~V}$ 亿定雷位保持して成長性䍜孔か らのき裂発生をしらべた，試片には複数の食孔をなるべく 合体が起らない上らに生成させた。，適当な繰返し数 $N$ で 試験機よりはずした試片上で観察した，最大食孔の深さ (・印)および光顕下にその内壁にき裂を観察しえた食孔の 深さ( $\Delta$ 印)を，Fig.1に示した。このように，孔食電位以 上の電位に打いて子食孔底比き裂生成が起る。しかし，き 裂性食孔内譬江和计る溶解之激しく競合する。

すなわち， $N=(150 \sim 250) \times 10^{3}$ 回，深さ $h=160 \sim 420$

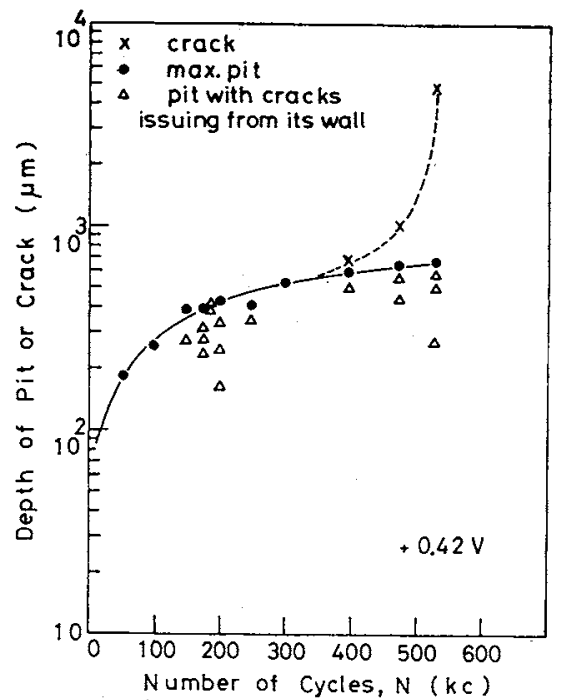

Fig. 1 Growth of pits and initiation of cracks at their walls at a potential of $0.42 \mathrm{~V}$, which is more noble than the critical pitting potential, $V_{c}=0.41 \mathrm{~V}(\mathrm{SCE})$. 
$\mu \mathrm{m}$ の食孔底部に $\Delta l=30 \sim 100 \mu \mathrm{m}$ 深さのき裂の生成を認 める。しかしこの期間汇生成したき裂は，Fig.1 において き裂を楒好ない $N=300 \times 10^{3}$ 回の前後に，鈍化あるいは 消失してしまち。試片を破断に導くような成長性き裂は， その後 $N=400 \times 10^{3}$ 回程度以降になって再び食孔底に生 成するき裂であって，その深さ $h+\Delta l$ の成長をFig.1 中 にメ卵で示した。

最大食孔深さの成舆から求め大食孔底溶解速度は， $N=$ (0〜150) $\times 10^{3}$ 回では $166 \mathrm{~mA} / \mathrm{cm}^{2}$ であるのが，き裂生成 の起る $N=(150 \sim 250) \times 10^{3}$ 回では $1 / 10$ 程度に小さくなる。 この溶解挙動は無応力下の場合む同じであった。すなわ ๖，沁力の存在とは哭関係に余孔底溶解速度が低下する期 間に，き裂生成が起っている。

\section{2. 活性態予き裂の不動態電位域における挙動}

活性態域に属する $E_{1}=-0.45 \mathrm{~V}$ で $N_{1}$ 回繰返して複数 のき裂(以下で活性態予き裂とよぶ)を試片に尊入したの ら，陚片の電位を不動態域電位 $E_{2}$ にさりかえて $N_{2}$ 期間 保持したときの，活性態予さ裂の形状または深さの変化を しらべた。

Fig. 2 は, $N_{1}=650 \times 10^{3}$ 问, $E_{2}=0.30 \mathrm{~V}, N_{2}=61 \times 10^{3}$

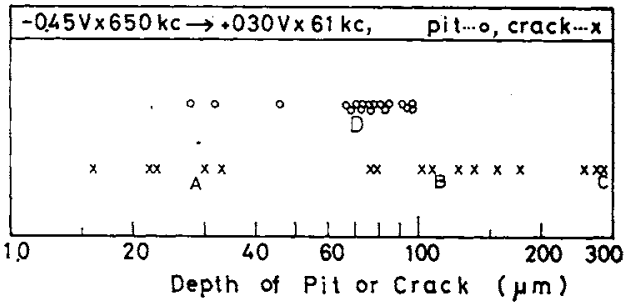

Fig.2 The behavior of the precracks with various depths which were introduced into the specimen at $-0.45 \mathrm{~V}$. In the figure it is shown that the precracks are found in the form of cracks $(x)$ or pits (O) depending on their final depths after a holding time of $61 \mathrm{kc}(45 \mathrm{~min})$ at a passive potential of $0.30 \mathrm{~V}$.

回(約 $45 \mathrm{~min}$ )といら処理を施した試片を開口処理後光顕 钼察し，主として先端の形状から判断して，き裂形態を保 っている(×印)か，传扎変わった（○印かをしらべ，そ れぞれの最終深さに対して示したものである。Fig.2中で $\mathrm{A} \sim \mathrm{D}$ と印したるのの破面をそれぞれPhoto.1(a〜d)に 示した。

活性態予き裂の不動態域での挙動は，そのサイズによっ て次の3つに大別される。
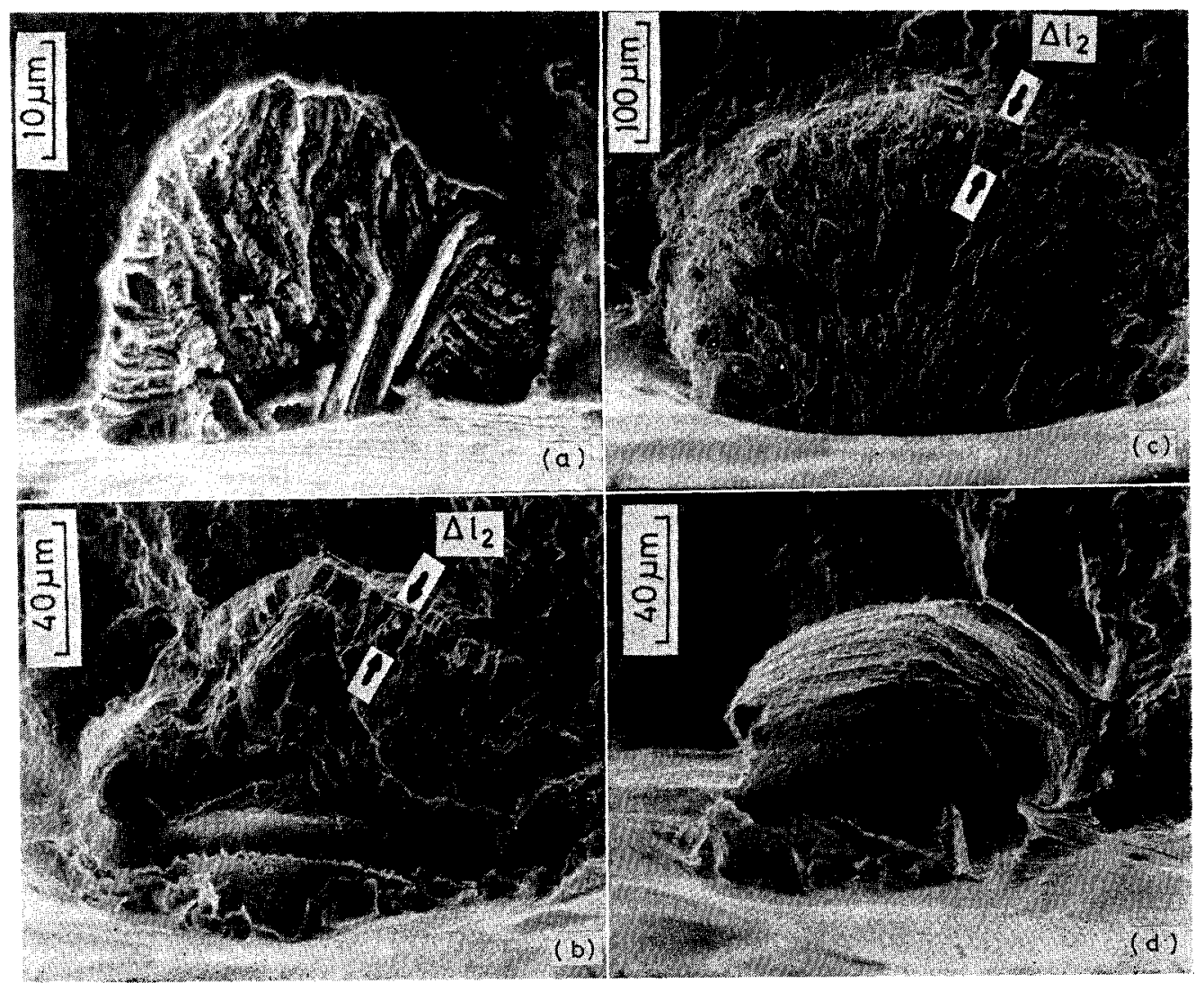

Photo.1 Scanning electron micrographs of the cracks $(a \sim c)$ and the pit $(d)$ which are denoted by the corresponding letters $(A \sim D)$ in Fig.2. An increment, $\Delta l_{2}$, is considered to be the subsequent extension at $0.30 \mathrm{~V}$ of the precrack. 
(1) サイズの小さいものは，不動態に保たれき裂として の成长もしないよらである。

Fig.2のA (深さ $30 \mu \mathrm{m}$ のき裂)は，その碳面 (Photo.1 (a)に新たな溶解のあとが認められないのは， $E_{2}=0.30 \mathrm{~V}$ では不動態に保たれていたからであるう。杰た， $N_{1}=350$ $\times 10^{3}$ 回で導入した活珄態予き裂の， $E_{2}=0.10,0.15$ 扰上 び $0.30 \mathrm{~V}$ に尔けるるっと長い保持期間にわたる举動を, $100 \mu \mathrm{m}$ 以下の浅いものについて Fig.3 25〜 40 $\mu \mathrm{m}$ を境として，これより深いき裂は食孔化し，浅 いき裂はき裂形態のまま成長もしないようである。

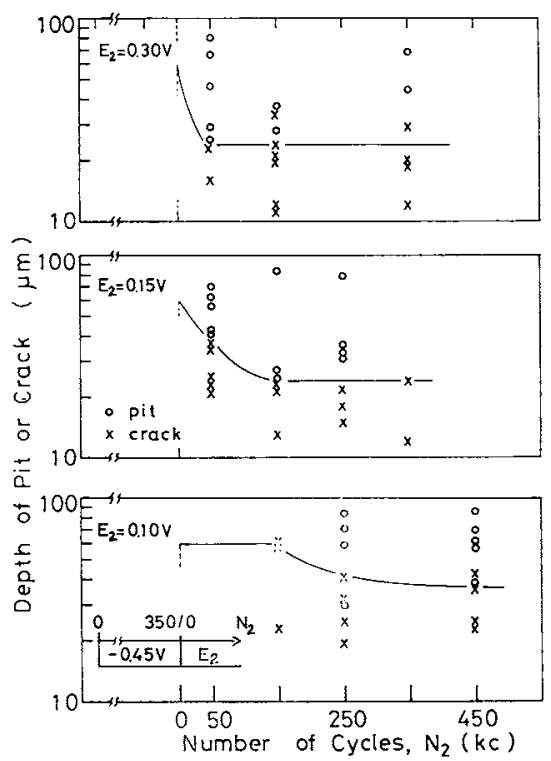

Fig.3 Depths of unchanged cracks $(x)$ and of pits (O) developed from precracks, observed on the precracked specimens after various holding times at the passive potentials.

(2)サイズの大きいき裂は，先端のき裂形態が保たれ成 長を継続する，後述する Fig.4の結果から深さ70〜80 $\mu \mathrm{m}$ 以上の予き裂がこれに該当する。これらき裂の破面では， 最終き裂先端心並行な帯状の破面部分が浅い䁚と区別して 識別されるが，これは予き裂を $E_{2}$ に $N_{2}$ 期間保持したと きのき裂の成長分 $\Delta l_{2}$ に相当すると考完られる．このこと を用いて，不動態域に竹けるき裂成長速度を測定した結果 は III.3に後述する。Fig. 2 のB (菆終深さ $108 \mu \mathrm{m}$ のき裂) の破面(Photo.1(b))に乱てを，先端のき裂形態は保たれ ているが，約 $36 \mu \mathrm{m}$ 樑さまでの内壁には半球形食孔に特 徽的な電解研摩型溶解, それ以降にはすきま腐食, のあと がそれぞれ観察される。ところが，樶終深さ $290 \mu \mathrm{m}$ とさ らに深いき裂であるCの破面(Photo.1(c))においては，き 裂先端に近い $\Delta l_{2}$ 部分に方位ピット等が琶められる他は， 試片表面に到るまでの内壁に新たな溶解のあとは全く観察 されない。

（3）中間のサイズのき裂は，半球形食孔に変わり成㷌す
る，Fig.2に拈いて，Bより浅い 67〜96 $\mu \mathrm{m}$ 深さ範囲に 多数の食孔(○印)がみられるが，同じ深さ域でのき裂( 印) はごく少ないすなわちこの籁目の活性態予き裂の大 部分は， $0.30 \mathrm{~V}, 61 \times 10^{3}$ 回の保持ですでた完全な（先疏に き裂形態を残さない)半球状の食孔に变わる。Photo.1(d) はその例である。予き裂の深さ約 $60 \mu \mathrm{m}$ のものが食孔に

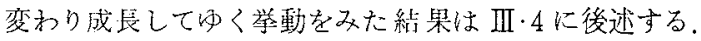

\section{3. 不動態電位域におけるき裂成長速度}

$E_{1}=-0.45 \mathrm{~V}$ で種々の深さの活性態予き裂を導入した Db, 不動態域電位 $E_{2}$ にきか光， $N_{2}=61 \times 10^{3}$ 回(約 $45 \mathrm{~min}$ )保持した，III·2(2)でのべた $\Delta l_{2}$ の意味によって， それぞれの $E_{2}$ 汇和いて测定した $\Delta l_{2} / N_{2}\left(N_{2}=61 \times 10^{3}\right.$ 国） を予き裂深さ $l_{1}$ に対して，Fig.4にまとめたこの不動 態琙化けるき裂成接速度は，き裂深さlの河数であって 試けの電位にはほとえど依存しない。戍示の直線は，き裂 樑さ $100 \mu \mathrm{m}$ 以上の範臤で次の上らに表わされる。

$$
\log i(l)=1.16 \log l-0.59
$$

ここに, $i(l)$ : 裂成長速度 $\left(\mathrm{A} / \mathrm{cm}^{2}\right), l$ : 裂深さ $(\mathrm{mm})$.

式（1）で表わされるき裂成長速度は，前報にのべた活性 態域火和叮るき裂成辰速度と比較すると，一0.20 なたは -0.50Vでの大きさにほぼ等しい。な誩，き裂破面上の， 大抵の場合 $\Delta l_{2}$ 部分に観察された方位ピットは，0.10 $0.30 \mathrm{~V}$ に拈いて $\{111\}+\{100\}$ の湿合 facet t.

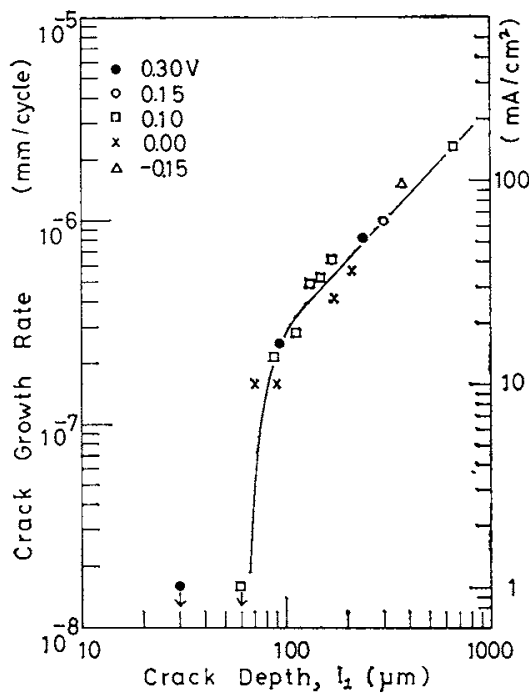

Fig.4 Crack growth rate in the passive potential range as a function of crack depth.

\section{4. 食孔底溶解速度}

$N_{2}=350 \times 10^{3}$ 回として，導入する活性態予き裂の最大 深さを約 $60 \mu \mathrm{m}$ におさえて， $E_{2}=0.10,0.15$ および 0.30 $\mathrm{V} に N_{2}$ 期間保拈したとき試片上に観察される最大の食孔 深さはFig.5 のようである.これは $E_{1}=-0.45 \mathrm{~V}$ で導入 
した約 $60 \mu \mathrm{m}$ 深さの活性態予裂が食孔亿変わり成長す る様子を表わするので㘯る。Fig.5 の直線の公配からそれ ぞれの $E_{2}$ に括ける位孔底溶解速度 $I_{\mathrm{h}}$ を求好て, Fig.6に 示した。 $0.42 \mathrm{~V}$ に扣斿る值 $166 \mathrm{~mA} / \mathrm{cm}^{2}(\mathbb{I I} \cdot 1)$ も書き込 んでいる。图示の直線は，陚片電位 $E(\mathrm{~V})$ と偍孔底溶解速 度 $I_{\mathrm{h}}\left(\mathrm{A} / \mathrm{cm}^{2}\right)$ との関係：

$$
E=0.30 \log I_{\mathbf{h}}+0.64
$$

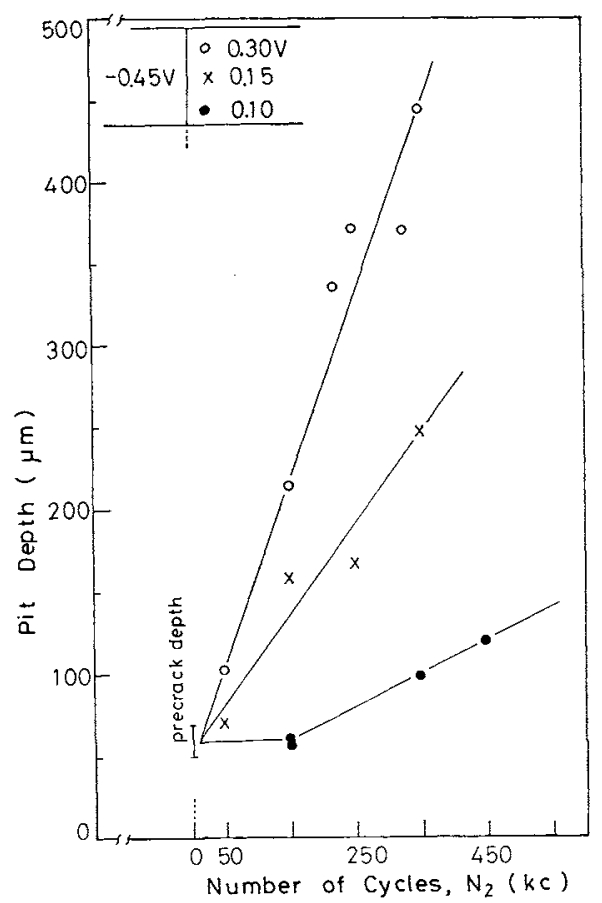

Fig.5 Subsequent growth of the precracks of $60 \mu \mathrm{m}$ in depth in the form of pits at the passive potentials. The precracks had been introduced by a test duration of $350 \mathrm{kc}$ at $-0.45 \mathrm{~V}$.

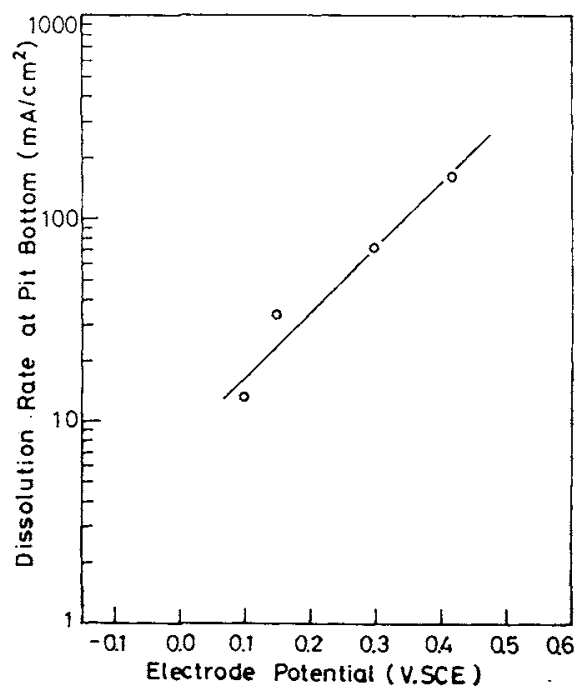

Fig.6 Dissolution rate at the pit bottom as a function of specimen potential.
である。こ机は，静留，無応力下の単一食孔について求め られたもの

このように一定電位保持条件下で成長する企孔は， $E_{2}=$ $0.10 \mathrm{~V}$ で惨い確率でき裂を伴うが， $E_{2}=0.15,0.30 \mathrm{~V}$ ではき裂を伴らことは極めて委れであった。

\section{5. 試片電位掃引降下条件下における食孔底の き裂生成}

$E_{1}=-0.45 \mathrm{~V}, N_{1}=350 \times 10^{3}$ 回繰返して最大約 $60 \mu \mathrm{m}$ 深さ以下の複数の活性態予裂を導入したのち，試片電位 を $E_{2}=0.30 \mathrm{~V}$ にきりか兄ると，繰返し数 $N_{2}$ の後には Fig. 5 亿示す食孔深さを最大とする複数の成長性食孔が党 られる，次いで，陚片電位を $240 \mathrm{~min} / \mathrm{V}$ の一定速度で下 げるといら操作を加党た，所定の電位に到着した時点で試 験機より陚片をとりはずし，食孔底に深さ $10 \mu \mathrm{m}$ 以上の き裂が生成した（メ印，開口処理後測定したき裂深さを $\mu \mathrm{m}$ 単位て附記)か，生成しなかった（○印)かをしらべ，この 結果を食孔深さ之到着電位とに対して Fig.7 に示した。到 着電位 $0.25 \mathrm{~V}$, 深さ $252 \mu \mathrm{m}$ の䬺孔底中央江生成した深さ $89 \mu \mathrm{m}$ のき裂をPhoto.2 亿示す。

Fig.7の上横軸は，下横軸间の電位 $E$ に対して式(2)の 関係化专る，领孔底溶解速度 $I_{\mathrm{h}}$ である。電位掃引降下中 食孔の深さは例示した定公配 ( $\left.35 \mu \mathrm{m} /-50 \mathrm{~mA} \cdot \mathrm{cm}^{-2}\right)$ の直

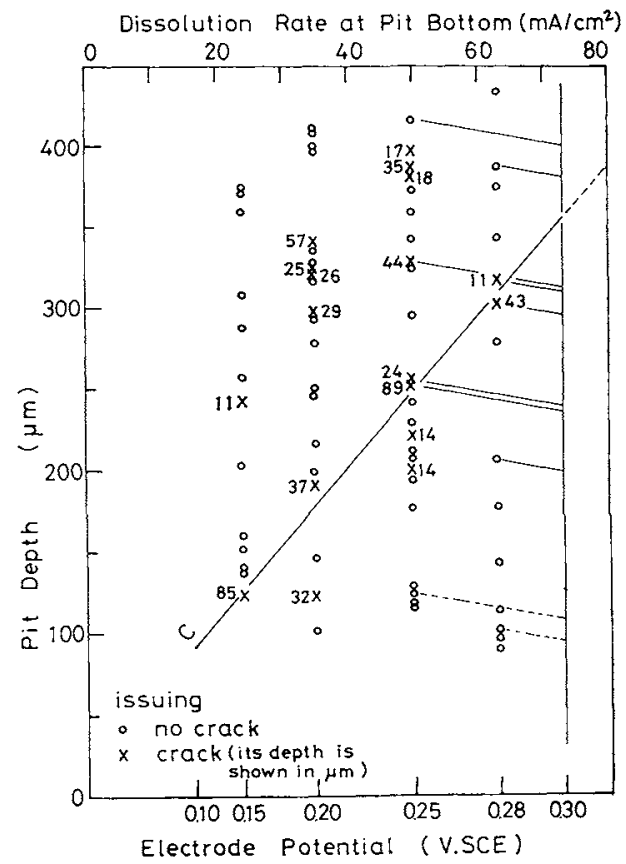

Fig.7 Occurrence $(x)$ or non-occurrence $(O)$ of crack initiation at the bottom of growing pits in relation to pit depth as well as specimen potential. The external potential of the specimen having growing pits of various depths that had been grown at $0.30 \mathrm{~V}$, was swept at a rate of 240 $\min / \mathrm{V}$ down to the values shown on the abcissa . 


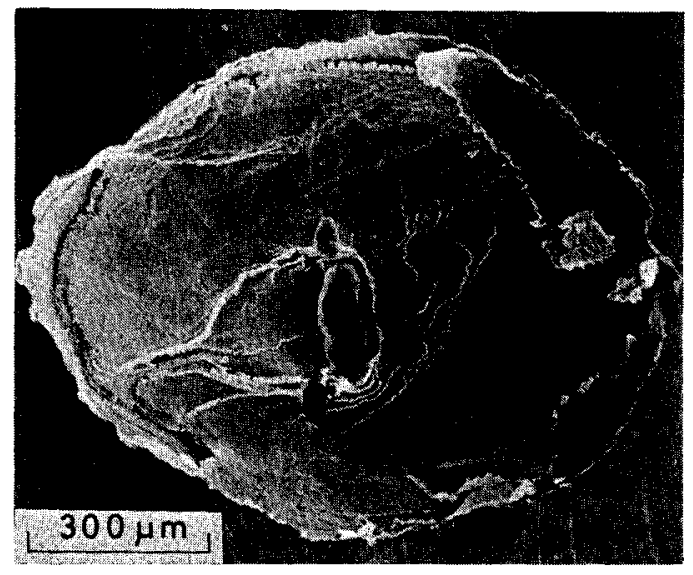

Photo.2 A growing pit with issuing crack at its bottom (after crack opening treatment).

線群のように成長してゆく ${ }^{(22)(23)}$. Fig.7 の結果から次の ことがわかる。

（1）自然食孔の性質を模した試片電位降下条件下では， 一定電位保持条件下に比し高い確率で食孔底にき笠生成が 起った，一なわち，その成長に伴って試片電位が贯化する といら自然食孔の本性 ${ }^{(24)}$ は，き裂発生を起こし晹い条件 をもっている。

（2）き裂生成を起す食孔の深さは，鼻な䉓位法ど浅い， これに関して因中の直線Cの意味は $\mathbb{N} \cdot 2$ に後述する。

（3）き裂生成の起った試片電位は，打拈よと $0.1 \sim 0.3 \mathrm{~V}$ である、これは，工にのべた村田らの報告に和ける割れ電 位域に汪添等しい。

電位掃引降下速度 $120 \mathrm{~min} / \mathrm{V}$ の場合も, 到着電位 0.25 $V$ に扣いて $240 \mathrm{~min} / \mathrm{V}$ の場合と间じ传孔深さ範眼にき裂 生成がみられたが，その深さは 15〜19 $\mu \mathrm{m}$ と, $240 \mathrm{~min} / \mathrm{V}$ の場合より浅かった。ささらに速い降下速度の下では，食孔 の成長継続そのものが著しく困難になる ${ }^{(20)}$.

Jones ${ }^{(25)}$ は， $0.1 \mathrm{~N} \mathrm{NaCl}$ を食导高温水中に和いて 304 鎡 Tube 電極の割れをしらべた報告の中で，き裂登生と電 位降下速度との相関を示要事実を観察している。すすから 動電位法で求めた孔食電位， $V_{c}^{\prime}$ ，より $200 \mathrm{mV}$ 貴な電位ま

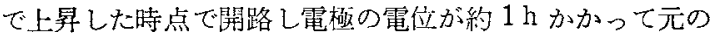
自然電位に降下したものにはピットを貫双くき裂を観察し たのに対して， $V_{c}^{\prime}+100 \mathrm{mV}$ で開路し約 $20 \mathrm{~min} て ゙$ 元の自 然電位まで降下した試片には明瞭な子毁す方楒めなかっ た，平均の電位隆下速度は，前者で $91 \mathrm{~min} / \mathrm{V}$, 後者で 36 $\min / \mathrm{N}$ でると見積られる。

\section{6. 食孔内壁の観察}

到着電位 $0.25 \mathrm{~V}$, 位孔深さ $320 \sim 330 \mu \mathrm{m}$ とほぼ同しで ある2つの食孔について，次のよらに観察された。き裂 (深さ $44 \mu \mathrm{m}$ ) を生成した一方の食孔底は全体になめらかで 孤立的方位ピットが散在するのみで西った。裂を生成し なかった他方の食孔揬には顕著なすべり線の突出が観察さ
れた。このよらな，き裂生成の有無に対応した内壁状態の ちがいは，Fig.7に放いて深さが直線 Cをこえた余孔につ いて佁く部察される。

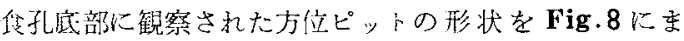
とめた。この図の目盛とりはFig.7 と同じである.Fig.7

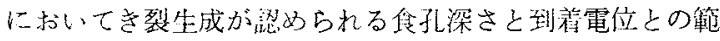
用に文られる方位ピットについてい充ば，

（1）位扎底皮膜下心ふた付で生呅なる。外接球直径で表 わした大きさが 20〜 $40 \mu \mathrm{m}$ に達してす外形は多角形に保 たれるが，内部の力位珄も維持されるのは10 $10 \mathrm{~m}$ 以下のあ のであった。これら方位と゚ットの facet $は\{111\}+\{100\} て$ あると钼察された。これ蚻，间じ電位域保持されたさ裂

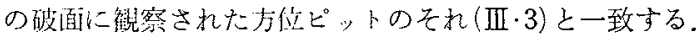

(2)き裂を伴うものが多数観察される．Fig.8ではこの ことを，き裂を意味する矢印付線分を付して表わした，食 孔底部で観察した2つの方位ピットをPhoto.3(a) と (b) に示可。六角の外形の外八非ているき裂(矢印)方，開口処 理をしないもの(Photo.3(a))ではわす゚かに想められる程度 であるが，開口処理をしたもの(Photo.3(b))では明瞭に観 察される。

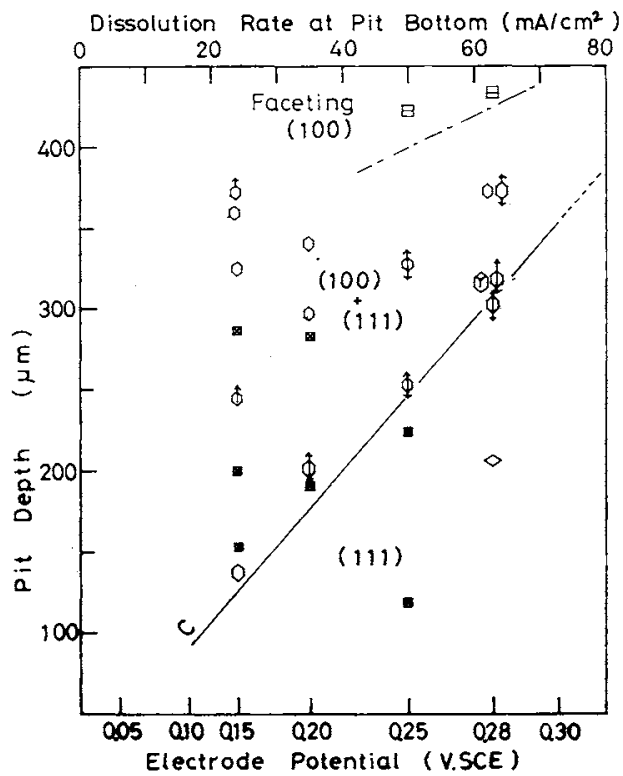

Fig.8 Residual planes of dissolution based on the shapes of crystallographic pits which were formed at the bottom of growing pits under the same condition as in Fig.7.

\section{IV. 考察}

\section{1.き裂生成の起点としての方位ピット}

Fig.7において食孔底にき裂生成が起った試片の電位

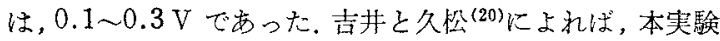
に用いたと同じ液中の 304 鋼の単一食孔において，0.2 $0.3 \mathrm{~V}$ といら試片電位(External Potential) は, 電位降下 

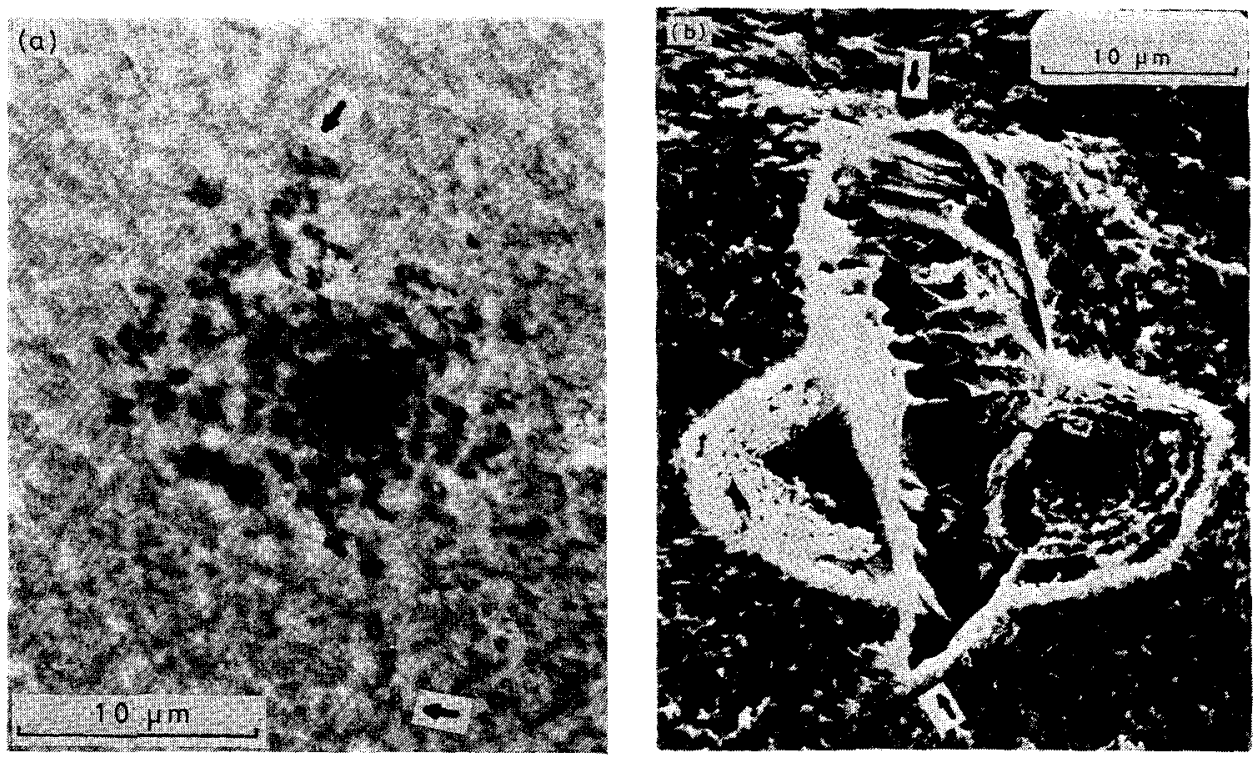

Photo.3 Crystallographic pits which were formed at the bottom of growing pits. Issuing cracks (indicated by the arrows) are visible not so clearly as removed from the fatigue tester (Photo.3(a)), but clearly after subsequent loading in tension above the yield point (crack opening treatment, Photo.3(b)).

条件下に食孔内壁上で活性溶解を行う部分が現われ始める ときの試片の電位である。全体的には半球形を保つ促孔の

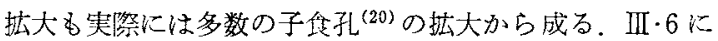
観察したき裂生成の起点としての方位ピットはこの子食 孔がその拡大の初期に方位性溶解をとったもので方ろう。 不動態化金属表面に生じる方位ピットを，その方位性を維 持しつつなるべく大きく成長させるためにとられる方法 は，定電流法 ${ }^{(26)}$ (電位が降下する)である。したがって，本 実験において食孔底にき裂生成を起し易加た，陚片電位 降下条件を，子食孔に和污る方位性溶解の維持に必要な条 件として理解することるできよう。

领孔底の SCC き裂生成に蛙故る方位ピットの介在に注 目したものとして，清水ら汇よる報告(11)がある。

発生するき裂と方位ピットとの関係を明確にするため, 㳄の実験を追加した，同じ 304 鋼平滑試片と溶液とを用い $0.20 \mathrm{~V} \times 20 \mathrm{~min}$ の不動態化処理後, 活性態域の $-0.25 \mathrm{~V}$ においてあらかじめ静此無応力下で $90 \mathrm{~min}$ 間方位ピット を成長させた後，同じ電位に保ったまま $80 \times 10^{3}$ 回(約 60 $\mathrm{min}$ )の期間応力振幅 $21.6 \mathrm{~kg} / \mathrm{mm}^{2}$ の回転曲げを与兄た。 方位ピット内壁の $\{111\}$ 面間の稯にき裂が生成し(Photo. 4), 方位ピットの外へ伸びてゆく(Photo.5)のが観察され た。いずれも開口処理を行っていないるのの写真である。

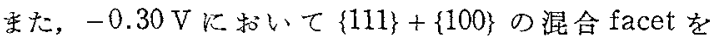
るつ方位ピットからは，さらに容烮にき裂生成が起ること も確かめられた。

\section{2. ミクロき裂の存続のための必要条件}

「深さhの成長性食孔底に生成した深さ $4 l$ のき裂」
… $C_{1}$ を想定する。このき裂の存続のために次の条件が必 要であるう。

$$
I_{\mathrm{h}} \leq I_{C}
$$

ここに， $I_{\mathrm{h}}$ : 传孔底溶解速度， $I_{C}$ : ミク口き裂 $C_{1}$ の成長 速度。式(3)を食孔深さと試片電位との関係で表現した

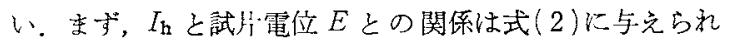
ている。主た，不動態域に和けるき裂，すなわち，

「試片表面から直接貫入した深さ $l$ の裂」… $C_{2}$ の成

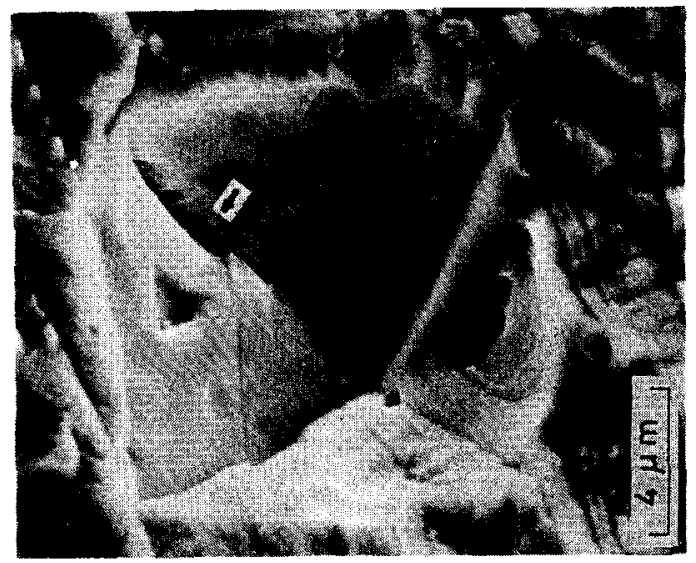

Photo.4 Nucleated crack at the intersection of two $\{111\}$ planes of the etch pit which was developed in the passivated steel surface by means of a potentiostatic technique at $-0.25 \mathrm{~V}$ for $90 \mathrm{~min}$. Rrotary bending for a duration of $80 \mathrm{kc}(60 \mathrm{~min})$ under a stress amplitude of $21.6 \mathrm{~kg} / \mathrm{mm}^{2}$ at the same potential. 


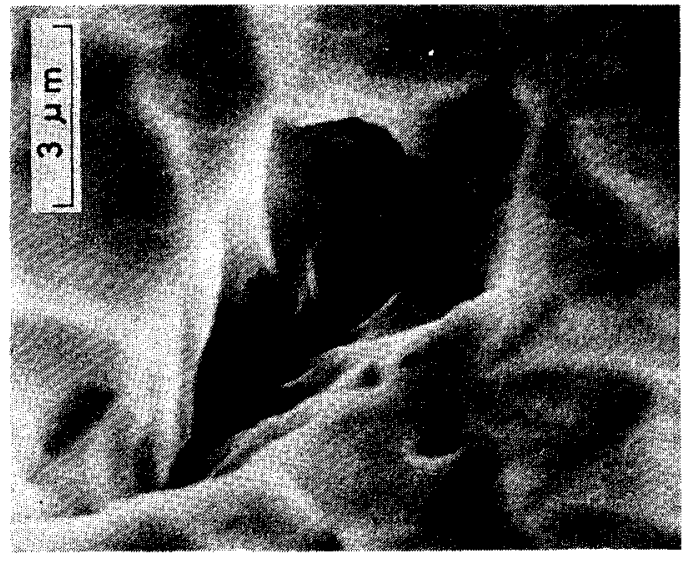

Photo.5 Another crack extending out of a etch pit observed in the same specimen as that of Photo. 4.

長速度は式 (1)で表わむれている。式（1)におけるき裂深 さlの意昧は力学的なものと考充られるので，C $C_{1}$ のそれと 等しい珫力払大係数 $K$ をもつ $C_{2}$ の染さがわかれば，式 (1)を用いて $C_{1}$ の成舆整度 $I_{C}$ を求め弓る。

このような問題に対する答は，2次元の場合は Fig.9

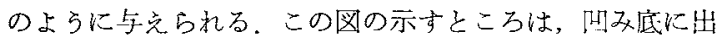
現したき裂に対する $K$ は，ごく小いいき裂サイズの段階 から急激に，四及深さに依存するものになっていくという ことである。これを参洘にして，いまの場合

$$
I_{C} \simeq i(h)
$$

すなわち， $C_{1}$ の成長涑度 $I_{C}$ は，位孔深さ $h$ に等しい深さ をむつき裂 $C_{2}$ の成長速度で近似しらる，とした。このと き式(3)は，

$$
I_{\mathbf{h}} \leq i(h)
$$

となり，式(1)と式 $(2)$ とを用いて，この関係を位孔深さ $h(\mathrm{~mm})$ と電位 $E(\mathrm{~V})$ とで表わすと，

$$
E \leq 0.35 \log h+0.46
$$

すなわ名，式(5)禾たは式 $(6)$ は，深さ $h$ の成長性俵孔底 のミクロき裂が存続しらるための必要条件である。式(6)

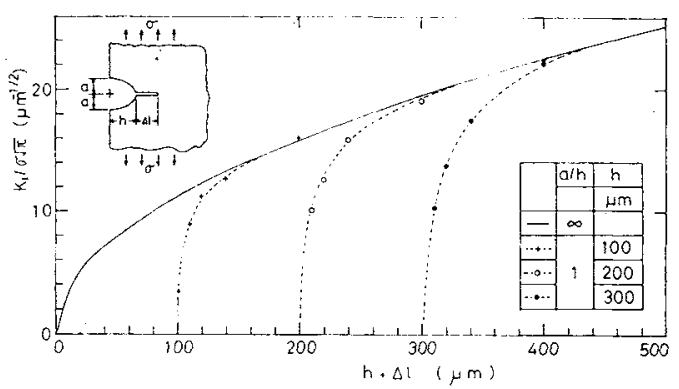

Fig.9 Normalized stress intensity factor for a crack emanating from a semicircular notch in a semiinfinite plate subjected to uniaxial tension.
の等号に相当する $E$ と $h$ との関係を值線Cとして，Fig.7 と Fig.8に記入した。

Fig.7 に示したさ裂生成範酒は，式(6)を满足すると文 なせる、したがって，III·5にのべた，「試牌電位が界な汪 ぞ，浅い铦孔からき裂が生成し易い」といら琤害は，式 （3）のような，ミク口き裂の成長速度と食孔底溶解速度と の競合関係から颜明しらるものと考光る。すなわb，ミク 口き裂そのものは方位ピットの作用により生成するとして ま，そのき裂が成長を継続しらるためには食孔底溶解速度 より大さいき裂成長速度をるつ必要がある。この必要条件 は，式(4)によれば，より㳭い俍孔底に生成したミク口き 裂ほど渾たし易い。

\section{V. 結 論}

$1 \mathrm{~N} \mathrm{H}_{2} \mathrm{SO}_{4}+0.5 \mathrm{M} \mathrm{NaCl}$ 溶液 $\left(25^{\circ} \mathrm{C}\right)$ 中で, 304 鎦の繰 返し荷重下に执ける，成長性食孔からのき裂発生をしらべ た.

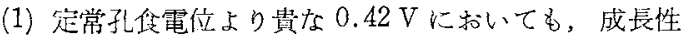
金扎底からき裂が発生する。

活性態域に属するー0.45 Vで導入されたき裂は，適当 な深さのとき不動態域電位に保持されると代孔に变わり成 長を繶ける—この成琵性定孔を不動態域において成長継 続している自然食孔と同等とみなして，これからのき裂発 生をしらべた結果，

（2）試片電位 $0.1 〜 0.3 \mathrm{~V}$ ，自然传孔の性質を模した試片 電位降下条件下に和いて，高い確率で毁孔底にき裂生成が 起った。

（3）（2）の場合の，早な電位汪ど浅い食孔からき裂が生 成し易いという特徽は，食孔底溶解速度より大きい成長速 度をむつき裂のみが実際に生成しうるといらことの反映で めると考觉られる。

（4）き裂生成の起点は，传孔庞に生じる方位ピットであ る。この方位ピットル叔る(100) faceting 溶解は，活性 態域に和けると同様に，き裂発生と高い相関をもつと考学 られる。

本研究の研究費の一部は著者の一人(过川)のらけた昭和 51年度一般研究 (D) 補助金によっていることを附記し謝意 を表する。また，笑騒結果の破壊力学的検討につきご教示 晹わった東京大学工学部船用機械工学科高野太刀雄氏感 辥する。

\section{文献}

(1) P.D.Neumann and J.C.Griess: Corrosion, 19 (1963) , $345 \mathrm{t}$.

（2）小若正倫，工滕赳夫：金属学会誌，37(1973)，1320.

(3) 小若正倫，工藤赴夫：鉄と鋼，62(1976), 390 .

(4) H.H. Uhlig and J.Lincoln, Jr. : J.Electrochem. Soc., 105(1958) , 325. 
(5) E.Brauns und H.Ternes : Werks. Korr., 19 (1968), 1 .

(6) W.W.Kirk, F.H. Beck and M.G. Fontana: Physical Metallurgy of Stress Corrosion Fracture, Ed.by T.N.Rodin, AIME, (1959), 227.

(7) R.W.Staehle, F.H.Beck and M.G.Fontana: Corrosion, 15(1959), 373 t.

（8）下瀨高明, 高村 昭, 森 慧二, 下郡一利：金属学 会誌，27(1963)，530.

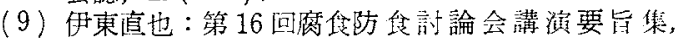
(1969), p.334.

(10) 熊田 誠：防食技術，22(1973)，274.

（11）清水達次，大崎修平，関弘也：第 17 回度全防垃 討論会講㴼要旨集, $(1970), \mathrm{p} .9$.

(12) F.Schreiber und H.J.Engell : Werks.Korr., 23 (1972), 255.

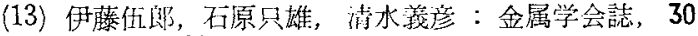
(1966), 888.

(14) 小苦正倫，冨土川尚琴：金属学会誌，34(1970)， 1054.

(15) S.J.Acello and N.D.Greene : Corrosion, 18 (1962), $286 \mathrm{t}$
(16) T.Murata and R.W. Staehle : The Theory of Stress Corrosion Cracking in Alloys, Ed. by J.C. Scully, NATO, Brussels, (1971), 223.

(17) S.Brennert : Recent Advances in Stress Corrosion, Royal Swedish Academy of Engineering Sciences, Stockholm, (1961).

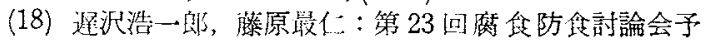
稿集, (1976), p.63.

(19) 过川淺男, 久松敬弘：金属学会誌，41(1977), 823 .

(20) 吉井緭泰，久松敬弘：金属学会誌，36(1972)，750.

(21) 吉井紹泰，久松敬弘，松村義一：金属学会誌，35 (1971), 633 .

(22) 久松敬弘：金属化学，11(1974)，59.

(23) Y.Hisamatsu : Passivity and Its Breakdown on Iron and Iron Base Alloys, USA-JAPAN Seminar, NACE, (1976), 99.

(24) 久松敬弘：防蝕技術，21(1972)，503.

(25) R.L.Jones : Corrosion, $31(1975), 424$.

(26) M.J.Czachor and Z.S.Smialowska : Corr. Sci., $8(1968), 215$.

(27) H.Tada, et a1. : The Stress Analysis of Cracks Handbook, Del Research, (1972), 19-13.

\section{非化学量論化合物 $\mathrm{NbSe}_{x}(x=1.48 \sim 2.00)$ の 熱力学的性質と結晶構造*}

\section{井 垣 謙 三** 西 根 士 郎***}

Kenzo Igaki and Shiro Nishine: Thermodynamic Properties and Crystal Structures of Nonstoichiometric Niobium Selenides $\mathrm{NbSe}_{x}$ for $x=1.48 \sim 2.00$. The pressurecomposition-temperature relations for niobium selenides $\mathrm{NbSe}_{\boldsymbol{x}}$ were determined by annealing under controlled selenium vapor pressure in the composition range $x=1.48 \sim 2.00$. Five phases were confirmed. Single crystals of these phases were grown by the chemical transport method, and their structures were determined by X-ray diffraction. Their ranges of stability are:

(1) Hexagonal $4 \mathrm{H}$ phase : above 5 Torr $\mathrm{Se}_{2}$ partial pressure at $900^{\circ} \mathrm{C}$ for $x=2.00$.

(2) The phase below 5 Torr $\mathrm{Se}_{2}$ partial pressure for $x=1.99 \sim 2.00$ is a $2 \mathrm{H}$ structure but probably different from $2 \mathrm{H}(\mathrm{b})$ structure proposed by $\mathrm{F}$. Jellinek, designated as $2 \mathrm{H}(\beta)$.

(3) Rhombohedral $3 \mathrm{R}$ phase : $1.80<x<1.86$ at $1000^{\circ} \mathrm{C}$ and $1.79<x<1.91$ at $900^{\circ} \mathrm{C}$.

(4) Hexagonal $2 \mathrm{H}$ (a) phase : $1.68<x<1.82$ at $1100^{\circ} \mathrm{C}$ and $1.66<x<1.76$ at $1000^{\circ} \mathrm{C}$.

(5) Monoclinic $\mathrm{Nb}_{2} \mathrm{Se}_{3}$ phase : $1.48<x<1.52$ at $1100^{\circ} \mathrm{C}$ and $1000^{\circ} \mathrm{C}$.

Within the stability range of the $3 \mathrm{R}$ and $2 \mathrm{H}$ (a) phases, the composition varies with $\mathrm{Se}_{2}$ pressure. These variations can be explained on statistical thermodynamic grounds by assuming that excess $\mathrm{Nb}$ atoms randomly occupy the octahedral interstitial sites of a stoichiometric $\mathrm{NbSe}_{2}$ structure.

(Received March 30, 1977)

\section{I. 緒言}

Nb-Se 系化合物の結鼠構造はJellinek らを初め多くの 人々によって研究されており(1)〜(8), 現在までに, $\mathrm{Nb}_{5} \mathrm{Se}_{4}$, $\mathrm{Nb}_{3} \mathrm{Se}_{4}, \mathrm{Nb}_{2} \mathrm{Se}_{3}, \mathrm{NbSe}_{2}, \mathrm{NbSe}_{4}$ の化合物の存在が報华さ
れ，その結晶構造す解析されている。. $\mathrm{NbSe}_{2}$ 相は $\mathrm{CdI}_{2}$ 型 に似た層状構造をとり，夲の層の積重なりのし方によって 種々の多形が存在することが報告されている. $\mathrm{NbSe}_{2}$ 相に おいて今まで確認されている構造を(11·0)断面でるって Fig.1 亿示す。 $\mathrm{NbSe}_{2}$ 相には1T(三方晶)，2 $\mathrm{H}(\mathrm{a})$ (六方

***東北大学工学部金属枋料工学科 (Department of Materials Science, Faculty of Engineering,

Tohoku University, Sendai)

*** 東北大学大学院 (Graduate Schoo1, Tohoku University, Sendai)

* 1976 年 10 月金属学会仙台大会恎よび 1977 年 4 月金属学会東京大会に発表 